\title{
Hyperbaric oxygen therapy for the management of chronic wounds: patient selection and perspectives
}

This article was published in the following Dove Press journal: Chronic Wound Care Management and Research

\author{
Enoch Huang' \\ Marvin Heyboer $3 r^{2}$ \\ Davut J Savaser' \\ 'Hyperbaric Medicine and Chronic \\ Wound Clinic, Legacy Emanuel Medical \\ Center, Portland, OR, USA; ${ }^{2}$ Emergency \\ Medicine, Division Chief, Hyperbaric \\ Medicine \& Wound Care, SUNY Upstate \\ Medical University, Syracuse, NY, USA
}

Correspondence: Enoch Huang Hyperbaric Medicine and Chronic Wound Clinic, Legacy Emanuel Medical Center, 300 I N. Gantenbein Ave., Portland, OR 97227, USA

Tel +50341333II

Email enoch.huang@mac.com

\begin{abstract}
The Undersea and Hyperbaric Medical Society includes "select problem wounds" as an accepted indication for the use of hyperbaric oxygen $\left(\mathrm{HBO}_{2}\right)$, however, the treatment of diabetic foot ulcers (DFUs) has dominated any discussions of problem wounds because of the prevalence of DFUs in today's patient population and the reimbursement available for their treatment. Other wound types (eg, calciphylaxis ulcers, sickle cell ulcers, and pyoderma gangrenosum) that have well-deserved reputations as problem wounds have been infrequently treated with $\mathrm{HBO}_{2}$. While there are sound fundamental reasons why additional oxygen may have benefits in the treatment of these wounds, the challenge is finding enough high quality evidence to support routine use of $\mathrm{HBO}_{2}$.

Keywords: hyperbaric oxygen therapy, $\mathrm{HBO}_{2}$, oxygen, problem wounds, chronic wounds, wound healing, diabetic foot ulcers, arterial insufficiency ulcers, sickle cell disease, scleroderma, calciphylaxis, graft versus host disease, pyoderma gangrenosum, venous stasis ulcers
\end{abstract}

\section{The role of oxygen in wound healing}

Oxygen is involved in nearly every phase of wound healing, acting as a critical cofactor for fibroblast replication, collagen deposition, ${ }^{1}$ angiogenesis, ${ }^{2-5}$ resistance to infection, ${ }^{6-8}$ and intracellular leukocyte bacterial killing. ${ }^{6}$ Tissue hypoxia, on the other hand, is the initiator of wound healing and leads to upregulation of hypoxiainducible factors (HIFs) that play a central role in adapting the body to a hypoxic environment. These adaptions include angiogenesis, anaerobic glycolysis, cellular mobility, growth factor signaling, and erythropoiesis. ${ }^{9}$ Wounds become hypoxic as a result of acute or chronic injury.

Hemostasis is the first phase of wound healing. Vasoconstriction, platelet aggregation, and formation of a fibrin clot stop bleeding but also cause local ischemia and hypoxia as vessels thrombose. ${ }^{10}$ Wound hypoxia is exacerbated by underlying conditions that result in decreased perfusion to the wound (eg, decreased cardiac output, increased peripheral vascular resistance, and presence of peripheral arterial disease [PAD] or pulmonary dysfunction). Oxygen carrying capacity is determined by the hemoglobin dissociation curve. Although anemia results in decreased overall $\mathrm{O}_{2}$ carrying capacity, it does not inherently inhibit wound healing. ${ }^{11}$ Arterial $\mathrm{pO}_{2}$ is the key factor in wound healing potential and can be modulated through vasodilation, improved cardiac output, capillary permeability, and increased alveolar $\mathrm{pO}_{2}$ achieved under hyperbaric conditions. ${ }^{10}$ 
The inflammatory phase begins a few days after injury as neutrophils and monocytes begin the process of breaking down and clearing cellular debris. ${ }^{10}$ Macrophages take the lead in breaking down devitalized tissue and killing bacteria, ${ }^{10,12}$ however, oxidative killing is depressed in patients with local wound hypoxia. A minimum tissue $\mathrm{pO}_{2}$ of $30 \mathrm{mmHg}$ is required for effective bacterial killing. ${ }^{7}$ Neutrophils killed $37 \%$ of organisms in 1 hour under anoxic conditions, $58 \%$ when $\mathrm{pO}_{2}$ was raised to 5 $\mathrm{mmHg}$, and $70 \%$ at $30 \mathrm{mmHg}$. There was a minimal increase in killing efficiency when tissue $\mathrm{pO}_{2}$ was further increased to $150 \mathrm{mmHg} .{ }^{13}$ Neutrophil bacterial killing activity depends on an oxygen-dependent respiratory burst where neutrophils convert oxygen to superoxide. ${ }^{14}$ This process can result in a 20-100 fold increase in oxygen consumption ${ }^{15,16}$ and a decrease in tissue $\mathrm{pO}_{2}$ from 60 mmHg down to $0-10 \mathrm{mmHg} .{ }^{17}$ Superoxide production is at its maximal rate at a tissue $\mathrm{pO}_{2}$ of $300 \mathrm{mmHg}$ but is cut in half with tissue $\mathrm{pO}_{2}$ between $80-150 \mathrm{mmHg} .{ }^{18}$ There is synergy between antibiotic administration and hyperoxia, as early antibiotic administration combined with hyperoxia resulted in more efficient bacterial clearance than delayed administration of either antibiotics or oxygen. ${ }^{8}$ Higher inspired oxygen has also been shown to decrease the spread of infectious necrosis. ${ }^{6}$

The proliferative phase of wound healing sees an increase in collagen deposition, angiogenesis, granulation tissue formation, and epithelialization, ${ }^{10}$ but all of these are directly related to wound $\mathrm{pO}_{2}{ }^{1,19-21}$ Fibroblast activity, especially collagen synthesis, is a key component in wound healing. Collagen cannot be synthesized without oxygen. ${ }^{22}$ The minimum tissue $\mathrm{pO}_{2}$ for collagen synthesis is $25 \mathrm{mmHg}$, so tissue $\mathrm{pO}_{2}$ below that results in decreased collagen deposition ${ }^{23}$ and lower quality collagen as tensile strength increases with high $\mathrm{pO}_{2}$ and decreases with high $\mathrm{pCO}_{2}{ }^{1}$ Angiogenesis and vasculogenesis are both increased through hyperoxia. ${ }^{24,25}$ Stem progenitor cells (SPCs) have been identified as playing a role in vasculogenesis, and studies suggest that HIF-1 plays an important role in directing circulating SPCs to ischemic tissue. ${ }^{9}$ The mitosis rate of squamous cells is oxygen dependent, ${ }^{26}$ and epithelialization increases with hyperoxia and decreases with hypoxia. ${ }^{20,27,28}$

Remodeling is the final phase of wound healing and occurs weeks to months after a wound is epithelialized. Immature collagen, which is thinner than mature collagen and deposited parallel to the skin, ${ }^{29}$ is reorganized into a more structurally sound lattice. Cross-linking of collagen fibers increases wound strength over the next $4-5$ weeks. ${ }^{10}$
Tensile strength of a newly epithelialized wound is only $3 \%$ at 1 week, $20 \%$ after 3 weeks, and $80 \%$ after 3 months. The ultimate strength of the wound depends on both the quality and quantity of the collagen, ${ }^{10}$ which is dependent on wound oxygenation.

In summary, acute injury causes wound hypoxia that is magnified if there is pre-existing ischemia and hypoxia in the wound. Wound $\mathrm{pO}_{2}$ further decreases as vessels thrombose in the hemostasis phase, leukocytes consume oxygen in the inflammatory phase, and fibroblasts consume oxygen in the proliferative phase. ${ }^{30}$ Importantly, a healing wound has a higher metabolic demand than when it is in a steady state. This is evidenced by depression of wound-tissue $\mathrm{pO}_{2}$ in the first few days after a major surgery. ${ }^{30}$ Wound $\mathrm{pO}_{2}$ is the rate limiting step in healing, especially in the acute postoperative phase, as the amount of $\mathrm{O}_{2}$ extracted rises with increased oxygen breathing. ${ }^{23}$

\section{Defining the chronic, problem wound}

A chronic wound can be defined as a wound that does not heal after an expected period of time. Chronic wounds are often trapped in the inflammatory phase of wound healing, unable to transition into the proliferative phase. Common causes for inflammation include infection, devitalized tissue that has been incompletely debrided, mechanical insults from retained foreign body or external pressure, and hypoxia as a result of wound ischemia. Initial efforts should focus on correcting or ruling out these causes of wound chronicity.

We have enumerated many examples where tissue hypoxia can hinder wound healing.

Local tissue hypoxia may be caused by macrovascular disease with or without concomitant microvascular disease. Macrovascular status can be evaluated using ankle-brachial index, pulse volume recordings, arterial Doppler, computed tomography/magnetic resonance angiogram, and angiography. Presence of macrovascular disease should result in a vascular consultation to determine whether revascularization is possible. Microvascular disease may be evaluated using skin perfusion pressure, transcutaneous oxygen measurement (TCOM), and indocyanine green fluorescence angiography (ICGA).

TCOM is a non-invasive study that measures the $\mathrm{pO}_{2}$ of tissue $\left(\mathrm{TcPO}_{2}\right)$ through intact skin. ${ }^{31}$ This provides an objective means of assessing local tissue hypoxia and identifying wounds with a high risk of non-healing or amputation. Electrodes are usually placed adjacent to the 
ulcer on the peri-wound skin while others may be placed on the contralateral limb for comparison or on the chest wall to measure normal values. $\mathrm{TcPO}_{2}$ values have been shown to be useful predictors of wound healing and response to hyperbaric oxygen $\left.\left(\mathrm{HBO}_{2}\right)\right)^{31-34} \mathrm{TcPO}_{2}$ measurements while breathing normobaric room air $<40$ $\mathrm{mmHg}$ are considered hypoxic and associated with a reduced likelihood of healing. $\mathrm{TcPO}_{2}$ values $<35 \mathrm{mmHg}$ while breathing $100 \%$ normobaric oxygen are associated with a $41 \%$ failure rate with $\mathrm{HBO}_{2} \cdot{ }^{33}$ A sea-level oxygen challenge can help predict whether a wound will respond to $\mathrm{HBO}_{2}$. A wound that is hypoxic on room air $\left(\mathrm{TcPO}_{2}<40\right.$ $\mathrm{mmHg}$ ) but has a rise in $\mathrm{TcPO}_{2}>35 \mathrm{mmHg}$ and more than double the room air $\mathrm{TcPO}_{2}$ while breathing $100 \%$ normobaric oxygen, is likely to benefit from $\mathrm{HBO}_{2} \cdot{ }^{33}$ The most valuable predictor of response to $\mathrm{HBO}_{2}$ is the $\mathrm{TcPO}_{2}$ while breathing $100 \% \mathrm{O}_{2}$ under hyperbaric conditions. ${ }^{32}$ An inchamber $\mathrm{TcPO}_{2}>200-299 \mathrm{mmHg}$ had significantly reduced wound failure rates. ${ }^{32}$ In-chamber $\mathrm{TcPO}_{2}>200$ $\mathrm{mmHg}$ had an $84 \%$ likelihood of benefit from $\mathrm{HBO}_{2}{ }^{33}$ while in-chamber $\mathrm{TcPO}_{2}<100 \mathrm{mmHg}$ had only a $14 \%$ likelihood of benefit from $\mathrm{HBO}_{2}{ }^{31}$

In-chamber $\mathrm{TcPO}_{2}$ was used to determine the appropriate treatment pressure for patients undergoing $\mathrm{HBO}_{2}$ to treat lower extremity wounds. ${ }^{35}$ The study used an inchamber $\mathrm{TcPO}_{2}$ target of $250 \mathrm{mmHg}$ for decision-making and demonstrated that nearly $80 \%$ of patients reached a $\mathrm{TcPO}_{2}>250 \mathrm{mmHg}$ at 2 ATA. For patients with a $\mathrm{TcPO}_{2}<250 \mathrm{mmHg}$ at 2 ATA, nearly half (41\%) reached a $\mathrm{TcPO}_{2}>250 \mathrm{mmHg}$ when chamber pressure was increased to 2.4 ATA. This monoplace-based $\mathrm{HBO}_{2}$ protocol allowed objective choice of treatment pressure that maximized benefit while minimizing risk. ${ }^{35}$

ICGA is a newer technology that assesses microvascular skin perfusion using an intravenous injection of ICG followed by imaging with a near-infrared laser camera. It has been used extensively by surgeons in the operating room. ${ }^{36-40}$ Recent publications have reported its use for $\mathrm{HBO}_{2}$ patients with soft tissue radionecrosis, ${ }^{41,42}$ and for assessing perfusion in chronic wounds being treated with $\mathrm{HBO}_{2} \cdot{ }^{43}$ While this is a very promising tool, there is more work that needs to be done to determine clinical decisionmaking parameters surrounding ICGA. ${ }^{44}$

While clinical evidence supports the use of $\mathrm{HBO}_{2}$ in the treatment of non-healing diabetic foot ulcers (DFUs), ${ }^{45,46}$ the variable results seen in actual clinical use suggest that we need to do a better job with patient selection. ${ }^{47}$ Patient selection becomes even more critical when considering $\mathrm{HBO}_{2}$ for less established problem wound types. Concern for tissue hypoxia or hypoperfusion should be considered before deciding to use adjunctive $\mathrm{HBO}_{2}{ }^{48}$ but it should not be the sole determinant in deciding to use $\mathrm{HBO}_{2}$ as some of its systemic effects (eg, endothelial progenitor stem cell mobilization) are not measured by tissue oxygenation. ${ }^{49,50}$

\section{Physiological effects of $\mathrm{HBO}_{2}$}

$\mathrm{HBO}_{2}$ addresses the fundamental issue of wound hypoxia by providing oxygen to ischemic tissue. The amount of $\mathrm{O}_{2}$ dissolved in plasma is inconsequential at sea-level atmospheric pressure; however, there is enough oxygen dissolved in plasma when breathing $100 \% \mathrm{O}_{2}$ at 3 ATA to meet the body's metabolic demands without dissociation of any $\mathrm{O}_{2}$ bound to hemoglobin. ${ }^{51}$ Oxygen diffusion from capillary beds increases ten-fold and $\mathrm{PaO}_{2}$ exceeds 1,500 $\mathrm{mmHg}$ with corresponding elevation of soft tissue and muscle $\mathrm{PO}_{2}$. Tissue $\mathrm{PO}_{2}$ increases in a direct linear relationship to the increased $\mathrm{PaO}_{2}$ present in the circulating plasma, ${ }^{52}$ allowing healing to proceed.

As opposed to breathing oxygen at sea-level atmospheric pressure, $\mathrm{HBO}_{2}$ reduces ischemia-reperfusion (IR) injury, mobilizes circulating SPCs, enhances neutrophil bacterial killing activity, produces both reactive oxygen species (ROS) and reactive nitrogen species (RNS), and stimulates multiple growth factors that promote wound healing. ${ }^{53} \mathrm{HBO}_{2}$ reduces the perivascular edema and inflammation seen with IR injury by inhibiting the adherence of neutrophils to previously ischemic vascular endothelium, but it does not inhibit the normal antimicrobial functions of degranulation, phagocytosis, or the oxidative burst. ${ }^{54-56} \mathrm{HBO}_{2}$ is involved in the recruitment and differentiation of circulating SPCs to form vessels de novo. $^{24,49,53}$ The knowledge that HIF-1 helps direct circulating SPCs to ischemic tissue ${ }^{9}$ suggests that the combination of HIF-1 activity and $\mathrm{HBO}_{2}$ may be the basis for improved healing seen with $\mathrm{HBO}_{2}$ therapy. ${ }^{57}$ Conversely, HIF-1 has been shown to break down rapidly in nonhypoxic environments ${ }^{58}$ and others have shown that $\mathrm{HBO}_{2}$ improves wound healing by down-regulating HIF$1 \alpha,{ }^{59}$ highlighting that we have an incomplete understanding of the complex interactions between HIF and $\mathrm{HBO}_{2}$.

ROS and RNS are important signaling molecules that are involved in the regulation of various hormones, growth factors, and cytokines involved in wound healing. ROS such as superoxide $\left(\mathrm{O}_{2}{ }^{-}\right)$, hydrogen peroxide $\left(\mathrm{H}_{2} \mathrm{O}_{2}\right)$, hypochlorous acid $(\mathrm{HClO})$, and hydroxyl $\left(\mathrm{HO}^{\circ}\right)$ are the 
natural by-products of normal metabolism, and RNS include nitric oxide (NO) and peroxynitrite $\left(\mathrm{ONOO}^{\circ}\right)$ the product of $\mathrm{NO}$ and $\mathrm{O}_{2}{ }^{--}$. $\mathrm{NO}$ is synthesized by three NO synthase enzymes: NOS-1 (nNOS), NOS-2 (iNOS), and NOS-3 (eNOS). Bone marrow eNOS activity is required for SPC mobilization - a function that is depressed in diabetic patients - and $\mathrm{HBO}_{2}$ is able to stimulate eNOS activity, resulting in up-regulation of SPC production. ${ }^{25,49,53,57}$ Reactive species may have either positive or negative effects, depending on their concentration and intracellular localization. ${ }^{60}$ A complete discussion of the role of ROS and RNS in wound healing is beyond the scope of this review, and readers are directed to Thom's manuscript for more details. ${ }^{60}$ The body needs to balance the ROS that are generated as a part of normal metabolism with its natural anti-oxidant defenses. An inability to maintain balance results in oxidative stress, which can be seen where an overproduction of ROS in chronic wounds leads to a prolonged inflammatory state. ${ }^{61}$ When speaking about $\mathrm{HBO}_{2}$, it is important to realize that oxidative stress and oxygen toxicity are not synonymous,${ }^{53}$ and the body's inherent anti-oxidant defenses are able to manage the oxidative stress seen in the intermittent use of $\mathrm{HBO}_{2}{ }^{62-68} \mathrm{NO}$, a potent vasodilator, is reduced in nonhealing diabetic wounds; however, increased NO levels after a course of $\mathrm{HBO}_{2}$ treatments correlated with successful healing. ${ }^{69}$

$\mathrm{HBO}_{2}$ increases synthesis of a laundry list of growth factors: VEGF, ${ }^{70}$ TGF- $\beta_{1}{ }^{71}$ bFGF, ${ }^{71}$ angiopoietin- $2,{ }^{72}$ MMP-2 and MMP-9, TIMP-1, ${ }^{73}$ and PDGF receptors. ${ }^{74}$ Collagen synthesis, which is very sensitive to $\mathrm{PO}_{2}$, is augmented by $\mathrm{HBO}_{2}{ }^{2}$ Epithelialization is increased by approximately $30 \%,{ }^{27}$ but wound contraction is unaffected by ambient $\mathrm{pO}_{2}{ }^{20} \mathrm{HBO}_{2}$ has been shown in cell cultures to up- or down-regulate over 8,000 different genes at the molecular and cellular level with large responses only when exposed to $\mathrm{HBO}_{2}$ and not sea-level $100 \%$ oxygen. $^{75}$

If oxygen availability is the rate limiting step in wound healing and $\mathrm{O}_{2}$ consumption increases as $\mathrm{O}_{2}$ availability increases, ${ }^{23}$ it stands to reason that further increases in available $\mathrm{pO}_{2}$ during $\mathrm{HBO}_{2}$ would enhance wound healing. In addition to the effects of hyperoxia, alternating periods of hypoxia or relative hypoxia (compared to $\mathrm{HBO}_{2}$ ) may stabilize HIF, which primes the wound for a more robust response during the next period of. ${ }^{76}$ This push-pull relationship may explain how $\mathrm{HBO}_{2}$ plays a role in enhanced healing of chronic, problem wounds.

\section{Patient selection for $\mathrm{HBO}_{2}$}

Although there are sound fundamental principles supporting the use of $\mathrm{HBO}_{2}$ for chronic wounds, ${ }^{77}$ the evidence for some of these conditions is limited to case reports and case series. There are very few randomized controlled trials, and the variability in scientific rigor has led many to question their conclusions. ${ }^{78}$

\section{DFUs}

The largest body of evidence in support of $\mathrm{HBO}_{2}$ is found in the treatment of DFUs. Patients with diabetes mellitus commonly have sensory, motor, and autonomic neuropathy as well as macrovascular and microvascular angiopathy, leading to ischemic and hypoxic wounds that are prone to ulceration and infection. ${ }^{79}$ There is decreased mobilization of circulating $\mathrm{SPCs}^{80}$ and suppression of $\mathrm{NO}$, reducing healing potential. As detailed previously, $\mathrm{HBO}_{2}$ reverses local tissue hypoxia, stimulates vasculogenesis, directs SPCs to ischemic tissue, and stimulates multiple growth factors that enhance wound healing and vasculogenesis. $^{49,53,69-71,74,81-83}$

A thorough summary and analysis of the hyperbaric literature regarding DFUs was published in $2017^{84}$ and updated in $2019 .{ }^{85}$ Readers are referred to these publications for a more in-depth discussion. Early studies showed that the use of $\mathrm{HBO}_{2}$ was able to reduce the incidence of lower extremity amputation. Amputation rates decreased from 30\%-40\% without $\mathrm{HBO}_{2}$ to only $5 \%$ with adjunctive $\mathrm{HBO}_{2}{ }^{86-89}$ Randomized controlled trials demonstrated that $\mathrm{HBO}_{2}$ reduced the number of positive wound cultures, ${ }^{90}$ reduced major amputation rates, ${ }^{88,90}$ and increased the rate of wound healing. ${ }^{91-94}$ Transcutaneous oximetry was shown to be a predictor of wound healing potential, but only when looking at TCOM values while breathing $\mathrm{HBO}_{2}{ }^{31-33,48,95} \mathrm{~A}$ fundamental tenet for the consideration of adjunctive $\mathrm{HBO}_{2}$ is whether or not basic wound care principles have been followed prior to instituting $\mathrm{HBO}_{2}{ }^{96,97}$ Criteria for the use of $\mathrm{HBO}_{2}$ were established in the United States by the Centers for Medicare and Medicaid Services (CMS) based on the result of a pivotal trial that utilized the Wagner Grading system ${ }^{88}$ even though there are other grading systems that are more sophisticated and arguably more clinically relevant. ${ }^{98}$

A large longitudinal cohort study of 6,259 patients with a plantar DFU questioned the effectiveness of $\mathrm{HBO}_{2}$, showing that patients receiving $\mathrm{HBO}_{2}$ had a lower healing rate (42.3\% vs $49.6 \%)$, higher overall amputation rate $(6.7 \%$ vs $2.1 \%)$, and higher major amputation rate $(3.3 \%$ vs $1.3 \%)$ than patients who did not receive $\mathrm{HBO}_{2}{ }^{47}$ This study 
highlighted the difference between the efficacy of $\mathrm{HBO}_{2}$ as shown in tightly controlled clinical trials vs how patients were treated in a real-world scenario, but it was criticized for its reliance on propensity scoring to account for the lack of randomization between treatment groups. ${ }^{91,99}$ Two recent randomized controlled trials also failed to show a benefit for $\mathrm{HBO}_{2}$ in healing DFUs or reducing amputations, ${ }^{100,101}$ but one was hampered by the use of photographs to adjudicate whether a wound met pre-determined criteria for amputation rather than amputation itself, ${ }^{102-104}$ and the other showed that a high percentage of patients did not start or could not complete the prescribed treatment protocol. ${ }^{105,106}$ When considering patients who did complete the protocol, however, $\mathrm{HBO}_{2}$ was able to show significantly fewer amputations than standard care alone. ${ }^{101}$ This is consistent with several other studies that showed that patients who underwent a longer course of therapy had successful wound healing, while those with shorter courses did not. ${ }^{31,107,108}$

The UHMS developed a set of clinical practice guidelines to help the hyperbaric provider judiciously use $\mathrm{HBO}_{2}$ as part of the treatment plan. Even though CMS guidelines restrict $\mathrm{HBO}_{2}$ for Wagner Grade 3 DFUs or higher, over $45 \%$ of patients in multiple studies had only Wagner Grade 2 DFUs. ${ }^{47,100,101}$ The UHMS found insufficient high-quality evidence to suggest using $\mathrm{HBO}_{2}$ in the treatment of Wagner Grade 2 DFUs. It did find enough evidence to suggest treating Wagner Grade 3 or higher DFUs that were either refractory to wound healing and had been present for 30 days, or for acutely infected Wagner Grade 3 or higher DFUs that required urgent surgical intervention. ${ }^{46} \mathrm{HBO}_{2}$ was shown to be more effective than standard therapy when restricted to only Wagner Grade 3 and 4 DFUs. ${ }^{108}$ Cost effectiveness studies comparing $\mathrm{HBO}_{2}$ with the cost of an amputation with subsequent rehabilitation and physical therapy have been uniformly favorable toward $\mathrm{HBO}_{2},{ }^{109-113}$ and the integration of $\mathrm{HBO}_{2}$ into a comprehensive limb salvage protocol has been advocated. ${ }^{87,113}$

DFUs remain the most common chronic wound type being treated with $\mathrm{HBO}_{2}$, but tightening requirements for reimbursement are constraining the frequency of its use. This may be wholly appropriate, given the rapid rise in outpatient wound and hyperbaric centers, ${ }^{114}$ but there is a risk of denying limbsaving therapy to a patient who truly requires it.

\section{Arterial insufficiency ulcers (AIUs)}

Between 8-12 million people in the United States over 40 years of age are affected by $\mathrm{PAD}^{115}$ and suffer tissue ischemia due to atherosclerosis. ${ }^{116}$ AIUs are closely related to DFUs as the majority of patients with DFU also have PAD. These patients are often unable to be revascularized, leaving an above-ankle amputation as their only alternative. Healing rates with revascularization are reported between $50 \%-90 \%$ with amputation rates of $<20 \%$. $^{117,118}$ Outcomes change dramatically without revascularization, however, with healing rates of $40 \%-50 \%$ and amputation rates between $25 \%-40 \%{ }^{117,118}$

$\mathrm{HBO}_{2}$ reverses local tissue hypoxia and stimulates vasculogenesis, however it is less effective in the face of severe macrovascular disease. Inability to revascularize the lower extremity is not a reason to exclude $\mathrm{HBO}_{2}$ from the treatment plan. A commonly overlooked aspect of the DFU studies previously mentioned is whether or not they include patients with underlying, uncorrectable vascular disease. While many wound healing studies excluded patients with significant PAD, the Faglia study included patients who had persistent tissue hypoxia and still showed increased healing and decreased amputation rates. ${ }^{88}$

There are very few studies to guide patient selection for $\mathrm{HBO}_{2}$, but a case series of 82 patients with AIUs in the absence of diabetes mellitus showed a significant clinical response to $\mathrm{HBO}_{2}{ }^{119}$ The Wound Healing Society recommends consideration of $\mathrm{HBO}_{2}$ if patients have an AIU refractive to revascularization or if they are not a candidate for revascularization. ${ }^{120}$ Any decision to use $\mathrm{HBO}_{2}$ for an AIU should be done after a thorough arterial insufficiency workup, although it may be considered as a bridging therapy to preserve ischemic tissue until definitive revascularization can occur. Objective measurements of tissue ischemia and hypoxia should be used to guide patient selection and monitor response to therapy, although there are no clear-cut criteria in the literature.

\section{Calciphylaxis}

Calciphylaxis is a rare condition that causes small vessel calcification of unknown etiology. This can present as painful skin lesions and chronic, non-healing ulcers with gangrene. Calciphylaxis is reported to have a prevalence of $1 \%-4 \%$ in end-stage renal disease patients on dialysis. ${ }^{121,122}$ Vascular calcification results in hypovascular tissue, fibrosis, and dermal necrosis, most often in the lower extremities. ${ }^{123}$ A mortality rate of $60 \%-80 \%$ is reported and is most often the result of septic complications of calciphylaxis wounds. ${ }^{124}$

$\mathrm{HBO}_{2}$ has been used for calciphylaxis wounds based on the rationale of hyperoxygenating ischemic tissue. Multiple case studies and case series have reported healing in previously refractive calciphylaxis wounds after a 
course of $\mathrm{HBO}_{2},{ }^{122,125-132}$ and concomitant use of $\mathrm{HBO}_{2}$ and thiosulfate has been advocated. ${ }^{131,132}$ Despite the fact that there are no high-quality studies that compare $\mathrm{HBO}_{2}$ to a control group, it has been used as a treatment of last resort after other standard therapies have failed. Logic dictates that earlier use of $\mathrm{HBO}_{2}$ would be more successful than later use of $\mathrm{HBO}_{2}$.

\section{Scleroderma}

Scleroderma is an autoimmune connective tissue disease that affects the hands, feet, and face. Abnormal thickening of the skin is caused by overproduction of collagen and subsequent damage to smaller arteries, resulting in local tissue hypoxia. ${ }^{133} \mathrm{HBO}_{2}$ is thought to improve healing by overcoming tissue hypoxia, ${ }^{32,134,135}$ although the effects of collagen modulation with $\mathrm{HBO}_{2}$ are unclear. Systemic scleroderma is an autoimmune disease, and $\mathrm{HBO}_{2}$ has been shown to play a role in minimizing the proliferation of damaging lymphocytes and modulating the biology of cytokines and inflammatory mediators. ${ }^{136,137}$

The evidence for the use of $\mathrm{HBO}_{2}$ in the treatment of scleroderma relies on case reports of refractive scleroderma wounds that have healed with $\mathrm{HBO}_{2} \cdot{ }^{138-145}$ Patient selection should rely on clinical judgement as to the likelihood that $\mathrm{HBO}_{2}$ can alter the trajectory of the scleroderma ulcer.

\section{Graft-versus-host disease (GvHD)}

Allogeneic stem cell transplantation in the treatment of hematopoietic and lymphatic malignancies may result in cutaneous complications of GvHD. The most common manifestations of GvHD are skin ulcers resulting from dermal/subcutaneous endothelial damage and microangiopathy. ${ }^{146-148} \mathrm{HBO}_{2}$ results in neovascularization and collagen deposition at the site of hypoxic tissue such as those in GvHD. ${ }^{24,53} \mathrm{HBO}_{2}$ may also play a role in immune modulation. $^{136,137}$

The evidence for use of $\mathrm{HBO}_{2}$ in GvHD relies on animal studies and case report data. ${ }^{149,150}$ Patient selection should rely on clinical judgement and may benefit from objective assessments of tissue perfusion and hypoxia to determine whether treatment is appropriate for individual patients.

\section{Pyoderma gangrenosum (PG)}

$\mathrm{PG}$ is a rare neutrophilic dermatosis that affects the skin and subcutaneous tissues. Histopathologic characteristics include edema and neutrophil infiltrates of small and medium-sized vessels. Thrombosis of these vessels results in surrounding hemorrhage. The neutrophil infiltration and inflammation can result in abscess formation with resultant liquefaction of the tissue. ${ }^{151}$

$\mathrm{HBO}_{2}$ has been utilized for decades for the treatment of $\mathrm{PG},{ }^{152-154}$ overcoming hypoxia and providing an antiinflammatory effect. A 2007 review provided a comprehensive listing of positive and negative case studies and concluded that $\mathrm{HBO}_{2}$ was an effective treatment option for cutaneous ulcers related to $\mathrm{PG}$, resulting in decreased pain and increased quality of life. ${ }^{153} \mathrm{HBO}_{2}$ may be considered for PG ulcers refractive to conventional therapies.

\section{Sickle cell disease (SCD)}

SCD is characterized by red blood cells that deform and take a sickled shape, impairing binding of oxygen, compromising circulation, producing ischemia, and causing anemia. $^{155}$ Approximately $2.5 \%$ of patients with SCD will develop a lower extremity ulcer. ${ }^{156} \mathrm{HBO}_{2}$ has been shown to reduce the percentage of circulating sickled cells after a hyperbaric exposure to 2 ATA. ${ }^{157,158}$

There is a single case report describing the use of $\mathrm{HBO}_{2}$ for two patients with SCD-related cutaneous wounds with a $50 \%$ response rate. ${ }^{159}$ There are both positive and negative case reports for the use of $\mathrm{HBO}_{2}$ in the treatment of pain crises, ${ }^{158,160,161}$ priapism, ${ }^{162}$ and central retinal artery occlusion ${ }^{163}$ complicated by SCD. There is insufficient evidence to support the routine use of $\mathrm{HBO}_{2}$ in the treatment of SCD ulcers, although it may be useful for non-cutaneous manifestations of SCD.

\section{Venous stasis ulcers (VLUs)}

VLUs account for $90 \%$ of ulcers of the lower extremity and are the result of uncontrolled leg edema. Edema decreases perfusion as intra-compartment pressures rise and compromise capillary flow. Compression therapy is the mainstay of therapy, reducing edema through augmentation of the calf pump and directly increasing extraluminal pressure. With uncontrolled edema, oxygen diffusion from capillary beds is reduced as the distance between capillaries increases as a result of cellular tumescence.

$\mathrm{HBO}_{2}$ has been found to reduce wound surface area following therapy in two randomized, sham controlled trials, but neither showed an improvement in healing rates. ${ }^{164,165}$ A third study did show statistically significant wound healing with $\mathrm{HBO}_{2} \cdot{ }^{166}$ There is insufficient evidence to support the routine use of $\mathrm{HBO}_{2}$ in the treatment of VLUs. 


\section{Conclusion}

The use of $\mathrm{HBO}_{2}$ for chronic, problem wounds is best defined for DFUs, but there is a sound fundamental basis for its use for some other chronic wound types. There is a lack of high-quality clinical evidence for non-DFU indications however, and providers must utilize clinical judgement to decide whether the reason for wound healing failure can be overcome with $\mathrm{HBO}_{2}$. Large clinical trials are unlikely to be successful given the rarity of these conditions, but participation in a research registry may allow pooled data to demonstrate efficacy of $\mathrm{HBO}_{2}$.

\section{Disclosure}

The authors report no conflicts of interest in this work.

\section{References}

1. Hunt TK, Pai MP. The effect of varying ambient oxygen tensions on wound metabolism and collagen synthesis. Surg Gynecol Obstet. 1972;135(4):561-567.

2. Hopf HW, Gibson JJ, Angeles AP, et al. Hyperoxia and angiogenesis. Wound Repair Regen. 2005;13(6):558-564. doi:10.1111/ j.1524-475X.2005.00078.x

3. Knighton DR, Silver IA, Hunt TK. Regulation of wound-healing angiogenesis-effect of oxygen gradients and inspired oxygen concentration. Surgery. 1981;90(2):262-270.

4. LaVan FB, Hunt TK. Oxygen and wound healing. Clin Plast Surg. 1990;17(3):463-472

5. Knighton DR, Hunt TK, Scheuenstuhl H, Halliday BJ, Werb Z, Banda MJ. Oxygen tension regulates the expression of angiogenesis factor by macrophages. Science. 1983;221(4617):1283-1285.

6. Knighton DR, Fiegel VD, Halverson T, Schneider S, Brown T, Wells CL. Oxygen as an antibiotic. The effect of inspired oxygen on bacterial clearance. Arch Surg. 1990;125(1):97-100.

7. Knighton DR, Halliday B, Hunt TK. Oxygen as an antibiotic. The effect of inspired oxygen on infection. Arch Surg. 1984;119 (2):199-204.

8. Knighton DR, Halliday B, Hunt TK. Oxygen as an antibiotic. A comparison of the effects of inspired oxygen concentration and antibiotic administration on in vivo bacterial clearance. Arch Surg. 1986;121(2):191-195.

9. Ruthenborg RJ, Ban JJ, Wazir A, Takeda N, Kim JW. Regulation of wound healing and fibrosis by hypoxia and hypoxia-inducible factor-1. Mol Cells. 2014;37(9):637-643. doi:10.14348/molcells.2014.0150

10. Janis JE, Harrison B. Wound healing: part I. Basic science. Plast Reconstr Surg. 2014;133(2):199e-207e. doi:10.1097/01. prs.0000437224.02985.f9

11. Heughan C, Grislis G, Hunt TK. The effect of anemia on wound healing. Ann Surg. 1974;179(2):163-167.

12. Knighton DR, Fiegel VD. Macrophage-derived growth factors in wound healing: regulation of growth factor production by the oxygen microenvironment. Am Rev Respir Dis. 1989;140 (4):1108-1111. doi:10.1164/ajrccm/140.4.1108

13. Hohn DC, MacKay RD, Halliday B, Hunt TK. Effect of O2 tension on microbicidal function of leukocytes in wounds and in vitro. Surg Forum. 1976;27(62):18-20.

14. Babior BM. Oxygen-dependent microbial killing by phagocytes (first of two parts). N Engl J Med. 1978;298(12):659-668. doi:10.1056/NEJM197803232981205
15. Babior BM. The respiratory burst of phagocytes. J Clin Invest. 1984;73(3):599-601. doi:10.1172/JCI111249

16. Tizard J. Destruction of foreign material - the myeloid system, neutrophils. In: Immunology: An Introduction. 3rd ed. Forth Worth (TX): Saunders College Publishing; 1992;26-37.

17. Silver IA. Tissue PO2 changes in acute inflammation. Adv Exp Med Biol. 1978;94:769-774.

18. Allen DB, Maguire JJ, Mahdavian M, et al. Wound hypoxia and acidosis limit neutrophil bacterial killing mechanisms. Arch Surg. 1997;132(9):991-996.

19. Niinikoski J. Effect of oxygen supply on wound healing and formation of experimental granulation tissue. Acta Physiol Scand Suppl. 1969;334:1-72.

20. Pai MP, Hunt TK. Effect of varying oxygen tensions on healing of open wounds. Surg Gynecol Obstet. 1972;135(5):756-758.

21. Kivisaari J, Vihersaari T, Renvall S, Niinikoski J. Energy metabolism of experimental wounds at various oxygen environments. Ann Surg. 1975;181(6):823-828.

22. Udenfriend S. Formation of hydroxyproline in collagen. Science. 1966;152:1335.

23. Hunt TK, Ellison EC, Sen CK. Oxygen: at the foundation of wound healing-introduction. World J Surg. 2004;28(3):291-293. doi:10.1007/s00268-003-7405-x

24. Velazquez OC. Angiogenesis and vasculogenesis: inducing the growth of new blood vessels and wound healing by stimulation of bone marrow-derived progenitor cell mobilization and homing. $J$ Vasc Surg. 2007;45(Suppl A):A39-47. doi:10.1016/j. jvs.2007.02.068

25. Thom SR, Milovanova TN, Yang M, et al. Vasculogenic stem cell mobilization and wound recruitment in diabetic patients: increased cell number and intracellular regulatory protein content associated with hyperbaric oxygen therapy. Wound Repair Regen. 2011;19 (2):149-161. doi:10.1111/j.1524-475X.2010.00660.x

26. Bullough WS, Johnson M. Epidermal mitotic activity and oxygen tension. Nature. 1957;167:488. doi:10.1038/167488a0

27. Winter G, Perrins D Effects of hyperbaric oxygen treatment on epidermal regeneration. Paper presented at: Fourth International Congress on Hyperbaric Medicine 1970; Tokyo.

28. Utkina O. Regeneration of the skin epithelium in healing wounds under noral conditions and at reduced baroetric pressure. Biol Abs. 1964;45:78585.

29. Broughton $\mathrm{G}$ 2nd, Janis JE, Attinger CE. Wound healing: an overview. Plast Reconstr Surg. 2006;117(7 Suppl):1e-S-32e-S. doi:10.1097/01.prs.0000222562.60260.f9

30. Chang N, Goodson WH 3rd, Gottrup F, Hunt TK. Direct measurement of wound and tissue oxygen tension in postoperative patients. Ann Surg. 1983;197(4):470-478.

31. Fife CE, Buyukcakir C, Otto G, Sheffield P, Love T, Warriner R 3rd Factors influencing the outcome of lower-extremity diabetic ulcers treated with hyperbaric oxygen therapy. Wound Repair Regen. 2007;15(3):322-331. doi:10.1111/j.1524-475X.2007.00234.x

32. Fife CE, Buyukcakir C, Otto GH, et al. The predictive value of transcutaneous oxygen tension measurement in diabetic lower extremity ulcers treated with hyperbaric oxygen therapy: a retrospective analysis of 1,144 patients. Wound Repair Regen. 2002;10 (4):198-207.

33. Fife CE, Smart DR, Sheffield PJ, Hopf HW, Hawkins G, Clarke D. Transcutaneous oximetry in clinical practice: consensus statements from an expert panel based on evidence. Undersea Hyperb Med. 2009;36(1):43-53.

34. Londahl M, Katzman P, Hammarlund C, Nilsson A, Landin-Olsson M. Relationship between ulcer healing after hyperbaric oxygen therapy and transcutaneous oximetry, toe blood pressure and ankle-brachial index in patients with diabetes and chronic foot ulcers. Diabetologia. 2011;54(1):65-68. doi:10.1007/s00125-0101946-y 
35. Heyboer M, Byrne J, Pons P, Wolner E, Seargent S, Wojcik SM. Use of in-chamber transcutaneous oxygen measurement to determine optimal treatment pressure in patients undergoing hyperbaric oxygen therapy. Undersea Hyperb Med. 2018;45(4):389-394.

36. Wormer BA, Huntington CR, Ross SW, et al. A prospective randomized double-blinded controlled trial evaluating indocyanine green fluorescence angiography on reducing wound complications in complex abdominal wall reconstruction. J Surg Res. 2016;202 (2):461-472. doi:10.1016/j.jss.2016.01.029

37. Colavita PD, Wormer BA, Belyansky I, et al. Intraoperative indocyanine green fluorescence angiography to predict wound complications in complex ventral hernia repair. Hernia. 2016;20(1):139149. doi:10.1007/s10029-015-1411-4

38. Furukawa H, Hayashi T, Oyama A, et al. Effectiveness of intraoperative indocyanine-green fluorescence angiography during inguinal lymph node dissection for skin cancer to prevent postoperative wound dehiscence. Surg Today. 2015;45(8):973-978. doi:10.1007/ s00595-014-0996-z

39. Wang HD, Singh DP. The use of indocyanine green angiography to prevent wound complications in ventral hernia repair with open components separation technique. Hernia. 2013;17(3):397-402. doi:10.1007/s10029-012-0935-0

40. Kitai T, Kawashima M, Fujii H, Mashima S, Shimahara Y. Indocyanine green fluorescence monitoring of perineal wound contamination in abdominoperineal resection: a preliminary report. Surg Today. 2011;41(8):1037-1040. doi:10.1007/s00595-010-4417-7

41. Johnson-Arbor K, Falola R, Kelty J, Barbour J, Attinger C. Use of indocyanine green fluorescent angiography in a hyperbaric patient with soft tissue radiation necrosis: a case report. Undersea Hyperb Med. 2017;44(3):273-278.

42. Arnold J, Marmolejo V. Visulization of angiogenesis and vasculogenesis in a late tissue radiation injury of the chest wall treated with adjuvant hyperbaric oxygen therapy using fluorescence angiography. Undersea Hyperb Med. 2019;46(1):5.

43. Kim D, Rao A, Kaplan S, et al. The use of indocyanine green fluorescence angiography to assess perfusion of chronic wounds undergoing hyperbaric oxygen therapy. Undersea Hyperb Med. 2018;45(6):9.

44. Huang E, Nichols T. Indocyanin green angriogaphy results preand post-hyperbaric oxygen exposure. Undersea Hyperb Med. 2016;43(6):1.

45. Londahl M. Hyperbaric oxygen therapy as adjunctive treatment of diabetic foot ulcers. Med Clin North Am. 2013;97(5):957-980. doi:10.1016/j.mcna.2013.04.004

46. Huang ET, Mansouri J, Murad MH, et al. A clinical practice guideline for the use of hyperbaric oxygen therapy in the treatment of diabetic foot ulcers. Undersea Hyperb Med. 2015;42(3):205-247.

47. Margolis DJ, Gupta J, Hoffstad O, et al. Lack of effectiveness of hyperbaric oxygen therapy for the treatment of diabetic foot ulcer and the prevention of amputation: a cohort study. Diabetes Care. 2013;36(7):1961-1966. doi:10.2337/dc12-2160

48. Moon H, Strauss MB, La SS, Miller SS. The validity of transcutaneous oxygen measurements in predicting healing of diabetic foot ulcers. Undersea Hyperb Med. 2016;43(6):641-648.

49. Thom SR, Bhopale VM, Velazquez OC, Goldstein LJ, Thom LH, Buerk DG. Stem cell mobilization by hyperbaric oxygen. Am J Physiol Heart Circ Physiol. 2006;290(4):H1378-1386. doi:10.1152/ajpheart.00888.2005

50. Heyboer M 3rd, Milovanova TN, Wojcik S, et al. CD34+/CD45dim stem cell mobilization by hyperbaric oxygen - changes with oxygen dosage. Stem Cell Res. 2014;12(3):638-645. doi:10.1016/j. scr.2014.02.005

51. Boerema I, Meyne NG, Brummelkamp WH, et al. [Life without blood]. Ned Tijdschr Geneeskd. 1960;104:949-954.

52. Hopf HW, Rollins MD. Wounds: an overview of the role of oxygen. Antioxid Redox Signal. 2007;9(8):1183-1192. doi:10.1089/ ars.2007.1641
53. Thom SR. Hyperbaric oxygen: its mechanisms and efficacy. Plast Reconstr Surg. 2011;127(Suppl 1):131S-141S. doi:10.1097/ PRS.0b013e3181fbe $2 \mathrm{bf}$

54. Juttner B, Scheinichen D, Bartsch S, et al. Lack of toxic side effects in neutrophils following hyperbaric oxygen. Undersea Hyperb Med. 2003;30(4):305-311.

55. Thom SR, Mendiguren I, Hardy K, et al. Inhibition of human neutrophil beta2-integrin-dependent adherence by hyperbaric $\mathrm{O} 2$. Am J Physiol. 1997;272(3 Pt 1):C770-777. doi:10.1152/ajpcell.1997.272.3.C770

56. Thom SR. Functional inhibition of leukocyte B2 integrins by hyperbaric oxygen in carbon monoxide-mediated brain injury in rats. Toxicol Appl Pharmacol. 1993;123(2):248-256. doi:10.1006/ taap. 1993.1243

57. Thom SR, Milavonova T. Hyperbaric oxygen therapy increases stem cell number and HIF-1 content in diabetics (Abstract). Undersea Hyperb Med. 2008;35(4):1.

58. Berra E, Roux D, Richard DE, Pouyssegur J. Hypoxia-inducible factor-1 alpha (HIF-1 alpha) escapes $\mathrm{O}(2)$-driven proteasomal degradation irrespective of its subcellular localization: nucleus or cytoplasm. EMBO Rep. 2001;2(7):615-620. doi:10.1093/emboreports/kve130

59. Zhang Q, Chang Q, Cox RA, Gong X, Gould LJ. Hyperbaric oxygen attenuates apoptosis and decreases inflammation in an ischemic wound model. J Invest Dermatol. 2008;128(8):21022112. doi: $10.1038 /$ jid.2008.53

60. Thom SR. Oxidative stress is fundamental to hyperbaric oxygen therapy. J Appl Physiol (1985). 2009;106(3):988-995. doi:10.1152/ japplphysiol.91004.2008

61. Schafer M, Werner S. Oxidative stress in normal and impaired wound repair. Pharmacol Res. 2008;58(2):165-171. doi:10.1016/j. phrs.2008.06.004

62. Dennog C, Gedik C, Wood S, Speit G. Analysis of oxidative DNA damage and HPRT mutations in humans after hyperbaric oxygen treatment. Mutat Res. 1999;431(2):351-359.

63. Dennog C, Hartmann A, Frey G, Speit G. Detection of DNA damage after hyperbaric oxygen (HBO) therapy. Mutagenesis. 1996;11(6):605-609.

64. Dennog C, Radermacher P, Barnett YA, Speit G. Antioxidant status in humans after exposure to hyperbaric oxygen. Mutat Res. 1999;428(1-2):83-89.

65. Rothfuss A, Dennog C, Speit G. Adaptive protection against the induction of oxidative DNA damage after hyperbaric oxygen treatment. Carcinogenesis. 1998;19(11):1913-1917.

66. Speit G, Dennog C, Eichhorn U, Rothfuss A, Kaina B. Induction of heme oxygenase-1 and adaptive protection against the induction of DNA damage after hyperbaric oxygen treatment. Carcinogenesis. 2000;21(10):1795-1799.

67. Speit G, Dennog C, Lampl L. Biological significance of DNA damage induced by hyperbaric oxygen. Mutagenesis. 1998;13 (1):85-87.

68. Speit G, Dennog C, Radermacher P, Rothfuss A. Genotoxicity of hyperbaric oxygen. Mutat Res. 2002;512(2-3):111-119.

69. Boykin JV Jr., Baylis C. Hyperbaric oxygen therapy mediates increased nitric oxide production associated with wound healing: a preliminary study. Adv Skin Wound Care. 2007;20(7):382-388. doi:10.1097/01.ASW.0000280198.81130.d5

70. Sheikh AY, Gibson JJ, Rollins MD, Hopf HW, Hussain Z, Hunt TK. Effect of hyperoxia on vascular endothelial growth factor levels in a wound model. Arch Surg. 2000;135(11):1293-1297.

71. Kang TS, Gorti GK, Quan SY, Ho M, Koch RJ. Effect of hyperbaric oxygen on the growth factor profile of fibroblasts. Arch Facial Plast Surg. 2004;6(1):31-35. doi:10.1001/archfaci.6.1.31

72. Lin S, Shyu KG, Lee CC, et al. Hyperbaric oxygen selectively induces angiopoietin-2 in human umbilical vein endothelial cells. Biochem Biophys Res Commun. 2002;296(3):710-715. 
73. Sander AL, Henrich D, Muth CM, Marzi I, Barker JH, Frank JM. In vivo effect of hyperbaric oxygen on wound angiogenesis and epithelialization. Wound Repair Regen. 2009;17(2):179-184. doi:10.1111/j.1524-475X.2009.00455.x

74. Bonomo SR, Davidson JD, Yu Y, Xia Y, Lin X, Mustoe TA. Hyperbaric oxygen as a signal transducer: upregulation of platelet derived growth factor-beta receptor in the presence of $\mathrm{HBO} 2$ and PDGF. Undersea Hyperb Med. 1998;25(4):211-216.

75. Godman CA, Chheda KP, Hightower LE, Perdrizet G, Shin DG, Giardina C. Hyperbaric oxygen induces a cytoprotective and angiogenic response in human microvascular endothelial cells. Cell Stress Chaperones. 2010;15(4):431-442. doi:10.1007/s12192-0090159-0

76. Chvapil M, Hurych J, Mirejovska E. Effect of long-term hypoxia on protein synthesis in granuloma and in some organs in rats. Proc Soc Exp Biol Med. 1970;135(3):613-617.

77. Worth ER, Tettelbach W, Hopf HW. Enhancement of Healing in Selected Problem Wounds. North Palm Beach (FL): Undersea and Hyperbaric Medical Society; 2014.

78. Kranke P, Bennett MH, Martyn-St James M, Schnabel A, Debus SE, Weibel S. Hyperbaric oxygen therapy for chronic wounds. Cochrane Database Syst Rev. 2015;(6):CD004123.

79. Dinh TL, Veves A. A review of the mechanisms implicated in the pathogenesis of the diabetic foot. Int J Low Extrem Wounds. 2005;4 (3):154-159. doi:10.1177/1534734605280130

80. Gallagher KA, Liu ZJ, Xiao M, et al. Diabetic impairments in NOmediated endothelial progenitor cell mobilization and homing are reversed by hyperoxia and SDF-1 alpha. J Clin Invest. 2007;117 (5):1249-1259. doi:10.1172/JCI29710

81. Goldstein LJ, Gallagher KA, Bauer SM, et al. Endothelial progenitor cell release into circulation is triggered by hyperoxia-induced increases in bone marrow nitric oxide. Stem Cells. 2006;24 (10):2309-2318. doi:10.1634/stemcells.2006-0010

82. Liu ZJ, Velazquez OC. Hyperoxia, endothelial progenitor cell mobilization, and diabetic wound healing. Antioxid Redox Signal. 2008;10(11):1869-1882. doi:10.1089/ars.2008.2121

83. Camporesi EM, Bosco G. Mechanisms of action of hyperbaric oxygen therapy.Undersea Hyperb Med. 2014;41(3):247-252.

84. Huang E, Heyboer M. Adjunctive hyperbaric oxygen therapy for diabetic foot ulcers. In: Whelan H, Kindwall E, editors. Hyperbaric Medicine Practice. 4th ed. North Palm Beach (FL): Best Publishing; 2018;591-622.

85. Huang E, Heyboer M, Savaser D. Enhancement of Healing in Selected Problem Wounds. North Palm Beach (FL): Undersea and Hyperbaric Medical Society; In press.

86. Baroni G, Porro T, Faglia E, et al. Hyperbaric oxygen in diabetic gangrene treatment. Diabetes Care. 1987;10(1):81-86.

87. Faglia E, Favales F, Aldeghi A, et al. Change in major amputation rate in a center dedicated to diabetic foot care during the 1980s prognostic determinants for major amputation. $J$ Diabetes Complications. 1998;12(2):96-102.

88. Faglia E, Favales F, Aldeghi A, et al. Adjunctive systemic hyperbaric oxygen therapy in treatment of severe prevalently ischemic diabetic foot ulcer. A randomized study. Diabetes Care. 1996;19 (12): $1338-1343$

89. Oriani G, Meazza D, Favales F, Pizzi G, Aldeghi A, Faglia E. Hyperbaric oxygen therapy in diabetic gangrene. $J$ Hyperbaric Med. 1990;5(3):171-175.

90. Doctor N, Pandya S, Supe A. Hyperbaric oxygen therapy in diabetic foot. J Postgrad Med. 1992;38(3):112-114.

91. Londahl M, Katzman P. Comments on Margolis et al. Lack of effectiveness of hyperbaric oxygen therapy for the treatment of diabetic foot ulcer and the prevention of amputation. Int Wound J. 2015;12(2):232. doi:10.1111/iwj.12093
92. Abidia A, Laden G, Kuhan G, et al. The role of hyperbaric oxygen therapy in ischaemic diabetic lower extremity ulcers: a doubleblind randomised-controlled trial. Eur J Vasc Endovasc Surg. 2003;25(6):513-518. doi:10.1053/ejvs.2002.1911

93. Duzgun AP, Satir HZ, Ozozan O, Saylam B, Kulah B, Coskun F. Effect of hyperbaric oxygen therapy on healing of diabetic foot ulcers. $J$ Foot Ankle Surg. 2008;47(6):515-519. doi:10.1053/j.jfas.2008.08.002

94. Ma L, Li P, Shi Z, Hou T, Chen X, Du J. A prospective, randomized, controlled study of hyperbaric oxygen therapy: effects on healing and oxidative stress of ulcer tissue in patients with a diabetic foot ulcer. Ostomy Wound Manage. 2013;59(3):18-24.

95. Strauss MB, Bryant BJ, Hart GB. Transcutaneous oxygen measurements under hyperbaric oxygen conditions as a predictor for healing of problem wounds. Foot Ankle Int. 2002;23(10):933-937. doi: $10.1177 / 107110070202301008$

96. Game FL, Attinger C, Hartemann A, et al. IWGDF guidance on use of interventions to enhance the healing of chronic ulcers of the foot in diabetes. Diabetes Metab Res Rev. 2016;32(Suppl 1):75-83. doi:10.1002/dmrr.2700

97. Game FL, Hinchliffe RJ, Apelqvist J, et al. A systematic review of interventions to enhance the healing of chronic ulcers of the foot in diabetes. Diabetes Metab Res Rev. 2012;28(Suppl 1):119-141. doi:10.1002/dmrr.2246

98. Game F. Classification of diabetic foot ulcers. Diabetes Metab Res Rev. 2016;32(Suppl 1):186-194. doi:10.1002/dmrr.2746

99. Carter MJ, Fife CE, Bennett M. Comment on: Margolis et al. Lack of effectiveness of hyperbaric oxygen therapy for the treatment of diabetic foot ulcer and the prevention of amputation: a cohort study. Diabetes Care. 2013;36:1961-1966. doi: $10.2337 / \mathrm{dc} 12-2160$

100. Fedorko L, Bowen JM, Jones W, et al. Hyperbaric oxygen therapy does not reduce indications for amputation in patients with diabetes with nonhealing ulcers of the lower limb: a prospective, doubleblind, randomized controlled clinical trial. Diabetes Care. 2016. doi: $10.2337 / \mathrm{dc} 15-2001$

101. Santema KTB, Stoekenbroek RM, Koelemay MJW, et al. Hyperbaric oxygen therapy in the treatment of ischemic lowerextremity ulcers in patients with diabetes: results of the DAMO2CLES multicenter randomized clinical trial. Diabetes Care. 2018;41(1):112-119. doi:10.2337/dc17-0654

102. Huang ET. Comment on Fedorko et al. Hyperbaric oxygen therapy does not reduce indications for amputation in patients with diabetes with nonhealing ulcers of the lower limb: a prospective, doubleblind, randomized controlled clinical trial. Diabetes Care. 2016;39:392-399. doi:10.2337/dc15-2001

103. Londahl M, Fagher K, Katzman P. Comment on Fedorko et al. Hyperbaric oxygen therapy does not reduce indications for amputation in patients with diabetes with nonhealing ulcers of the lower limb: a prospective, double-blind, randomized controlled clinical trial. Diabetes Care. 2016;39:392-399. doi:10.2337/dc15-2001

104. Murad MH. Comment on Fedorko et al. Hyperbaric oxygen therapy does not reduce indications for amputation in patients with diabetes with nonhealing ulcers of the lower limb: a prospective, double-blind, randomized controlled clinical trial. Diabetes Care. 2016;39:392-399. doi:10.2337/dc15-2001

105. Huang E. Comment on Santema et al. Hyperbaric oxygen therapy in the treatment of ischemic lower-extremity ulcers in patients with diabetes: results of the DAMO2CLES multicenter randomized clinical trial. Diabetes Care. 2018;41:112-119. doi:10.2337/dc17-0654

106. Mutluoglu M. Comment on Santema et al. Hyperbaric oxygen therapy in the treatment of ischemic lower-extremity ulcers in patients with diabetes: results of the DAMO2CLES multicenter randomized clinical trial. Diabetes Care. 2018;41:112-119. doi:10.2337/dc17-0654 
107. Londahl M, Katzman P, Nilsson A, Hammarlund C. Hyperbaric oxygen therapy facilitates healing of chronic foot ulcers in patients with diabetes. Diabetes Care. 2010;33(5):998-1003. doi:10.2337/dc09-1754

108. Ennis W, Huang E, Gordon H. Impact of hyperbaric oxygen on more advanced wagner grades 3 and 4 diabetic foot ulcers: matching therapy to specific wound conditions. Adv Wound Care. 2018;7 (12):11. doi:10.1089/wound.2018.0855

109. Guo S, Counte MA, Gillespie KN, Schmitz H. Cost-effectiveness of adjunctive hyperbaric oxygen in the treatment of diabetic ulcers. Int J Technol Assess Health Care. 2003;19(4):731-737.

110. Chuck AW, Hailey D, Jacobs P, Perry DC. Cost-effectiveness and budget impact of adjunctive hyperbaric oxygen therapy for diabetic foot ulcers. Int J Technol Assess Health Care. 2008;24(2):178-183. doi:10.1017/S0266462308080252

111. Hailey D, Jacobs P, Perry D, Chuck A, Morrison A, Boudreau R. Adjunctive hyperbaric oxygen therapy for diabetic foot ulcer: an economic analysis. Can Agency Drugs Technol Health. March 2007;2007.

112. Cianci P, Petrone G, Drager S, Lueders H, Lee H, Shapiro R. Salvage of the problem wound and potential amputation with wound care and adjunctive hyperbaric oxygen therapy: an economic analysis. J Hyperbaric Med. 1988;3(3):127-141.

113. Eggert JV, Worth ER, Van Gils CC. Cost and mortality data of a regional limb salvage and hyperbaric medicine program for Wagner grade 3 or 4 diabetic foot ulcers. Undersea Hyperb Med. 2016;43(1):1-8.

114. Huang ET. Hyperbaric medicine today: an historically noble discipline challenged by loss of critical access and overutilization - an introduction to invited commentary. Undersea Hyperb Med. 2017;44(1):1-3.

115. Rosamond W, Flegal K, Furie K, et al. Heart disease and stroke statistics-2008 update: a report from the American Heart Association Statistics Committee and Stroke Statistics Subcommittee. Circulation. 2008;117(4):e25-146. doi:10.1161/CIRCULATIONAHA.107.187998

116. Thomas DR. Managing peripheral arterial disease and vascular ulcers. Clin Geriatr Med. 2013;29(2):425-431. doi:10.1016/j. cger.2013.01.010

117. Marston WA, Davies SW, Armstrong B, et al. Natural history of limbs with arterial insufficiency and chronic ulceration treated without revascularization. J Vasc Surg. 2006;44(1):108-114. doi:10.1016/j.jvs.2006.03.026

118. Tautenhahn J, Lobmann R, Koenig B, Halloul Z, Lippert H, Buerger T. The influence of polymorbidity, revascularization, and wound therapy on the healing of arterial ulceration. Vasc Health Risk Manag. 2008;4(3):683-689.

119. Heyboer M 3rd, Grant WD, Byrne J, et al. Hyperbaric oxygen for the treatment of nonhealing arterial insufficiency ulcers. Wound Repair Regen. 2014;22(3):351-355. doi:10.1111/wrr.12176

120. Hopf HW, Ueno C, Aslam R, et al. Guidelines for the treatment of arterial insufficiency ulcers. Wound Repair Regen. 2006;14(6):693710. doi:10.1111/j.1524-475X.2006.00177.x

121. Angelis M, Wong LL, Myers SA, Wong LM. Calciphylaxis in patients on hemodialysis: a prevalence study. Surgery. 1997;122 (6):1083-1089; discussion 1089-1090.

122. Podymow T, Wherrett C, Burns KD. Hyperbaric oxygen in the treatment of calciphylaxis: a case series. Nephrol Dial Transplant. 2001;16(11):2176-2180.

123. Bhambri A, Del Rosso JQ. Calciphylaxis: a review. J Clin Aesthet Dermatol. 2008;1(2):38-41.

124. Budisavljevic MN, Cheek D, Ploth DW. Calciphylaxis in chronic renal failure. J Am Soc Nephrol. 1996;7(7):978-982.

125. An J, Devaney B, Ooi KY, Ford S, Frawley G, Menahem S. Hyperbaric oxygen in the treatment of calciphylaxis: a case series and literature review. Nephrology (Carlton). 2015;20(7):444-450. doi:10.1111/nep. 12433
126. Basile C, Montanaro A, Masi M, Pati G, De Maio P, Gismondi A. Hyperbaric oxygen therapy for calcific uremic arteriolopathy: a case series. J Nephrol. 2002;15(6):676-680.

127. Arenas MD, Gil MT, Gutierrez MD, et al. Management of calcific uremic arteriolopathy (calciphylaxis) with a combination of treatments, including hyperbaric oxygen therapy. Clin Nephrol. 2008;70 (3):261-264.

128. Don BR, Chin AI. A strategy for the treatment of calcific uremic arteriolopathy (calciphylaxis) employing a combination of therapies. Clin Nephrol. 2003;59(6):463-470.

129. Dean SM, Werman H. Calciphylaxis: a favorable outcome with hyperbaric oxygen. Vasc Med. 1998;3(2):115-120. doi:10.1177/ 1358836X9800300205

130. Vassa N, Twardowski ZJ, Campbell J. Hyperbaric oxygen therapy in calciphylaxis-induced skin necrosis in a peritoneal dialysis patient. Am J Kidney Dis. 1994;23(6):878-881.

131. McCulloch N, Wojcik SM, Heyboer M 3rd. Patient outcomes and factors associated with healing in calciphylaxis patients undergoing adjunctive hyperbaric oxygen therapy. J Am Coll Clin Wound Spec. 2015;7(1-3):8-12. doi:10.1016/j.jccw.2016.08.004

132. Baldwin C, Farah M, Leung M, et al. Multi-intervention management of calciphylaxis: a report of 7 cases. Am J Kidney Dis. 2011;58(6):988-991. doi:10.1053/j.ajkd.2011.06.022

133. Moran ME. Scleroderma and evidence based non-pharmaceutical treatment modalities for digital ulcers: a systematic review. $J$ Wound Care. 2014;23(10):510-516. doi:10.12968/jowc.2014.23.10.510

134. Rollins MD, Gibson JJ, Hunt TK, Hopf HW. Wound oxygen levels during hyperbaric oxygen treatment in healing wounds. Undersea Hyperb Med. 2006;33(1):17-25.

135. Tibbles PM, Edelsberg JS. Hyperbaric-oxygen therapy. $N$ Engl J Med. 1996;334(25):1642-1648. doi:10.1056/NEJM199606203342506

136. Gassas A, Wayne Evans A, Armstrong C, Doyle JJ. Open wound chronic skin graft-vs-host disease. Are these wounds ischemic? Pediatr Transplant. 2007;11(1):101-104. doi:10.1111/j.13993046.2006.00582.x

137. Al-Waili NS, Butler GJ. Effects of hyperbaric oxygen on inflammatory response to wound and trauma: possible mechanism of action. ScientificWorldJournal. 2006;6:425-441. doi:10.1100/tsw.2006.78

138. Dowling GB, Copeman PW, Ashfield R. Raynaud's phenomenon in scleroderma treated with hyperbaric oxygen. Proc $R$ Soc Med. 1967;60(12):1268-1269.

139. Chun W, Kim S, Seong H, Chong T. Hyperbaric oxygen therapy in systemic scleroderma. Korean J Dermatol. 1974;12(1):4.

140. Slade B. The Effect of hyperbaric oxygen therapy (HBO) on wound healing in patients with collagen-vascular disease: a retrospective analysis. Undersea Biomed Res. 1991;18(Suppl):1.

141. Markus YM, Bell MJ, Evans AW. Ischemic scleroderma wounds successfully treated with hyperbaric oxygen therapy. $J$ Rheumatol. 2006;33(8):1694-1696.

142. Gerodimos C, Stefanidou S, Kotsiou M, Melekos T, Mesimeris T. Hyperbaric oxygen treatment of intractable ulcers in a systemic sclerosis patient. Aristotle Univ Med J. 2013;40(3):4.

143. Li Y, Pang J, Miao L, Yu M. The long-term effect of hyperbaric oxygen therapy on systemic sclerosis. Guide of China Medicine. 2013. Available from: http://en.cnki.com.cn/Article_en/CJFDTotalYYXK201317339.htm. Accessed May 06, 2019.

144. Poirier E, Wind H, Cordel N. [Efficacy of hyperbaric oxygen therapy in the treatment of ischemic toe ulcer in a patient presenting systemic sclerosis]. Ann Dermatol Venereol. 2017;144(1):5559. doi:10.1016/j.annder.2016.06.007

145. Mirasoglu B, Bagli BS, Aktas S. Hyperbaric oxygen therapy for chronic ulcers in systemic sclerosis - case series. Int J Dermatol. 2017;56(6):636-640. doi:10.1111/ijd.13570 
146. Hymes SR, Alousi AM, Cowen EW. Graft-versus-host disease: part I. Pathogenesis and clinical manifestations of graft-versus-host disease. J Am Acad Dermatol. 2012;66(4):515e511-518; quiz 533-514. doi:10.1016/j.jaad.2011.11.960

147. Stussi G, Tsakiris DA. Late effects on haemostasis after haematopoietic stem cell transplantation. Hamostaseologie. 2012;32(1):6366. doi:10.5482/ha-1184

148. Biedermann BC, Sahner S, Gregor M, et al. Endothelial injury mediated by cytotoxic $\mathrm{T}$ lymphocytes and loss of microvessels in chronic graft versus host disease. Lancet. 2002;359(9323):2078-2083.

149. Song XY, Sun LN, Zheng NN, Zhang HP. Effect of hyperbaric oxygen on acute graft-versus-host disease after allogeneic bone marrow transplantation. Zhongguo Shi Yan Xue Ye Xue Za Zhi. 2008;16(3):623-626

150. Heyboer M 3rd, Taylor J, Morgan M, Mariani P, Jennings S. The use of hyperbaric oxygen therapy in the treatment of non-healing ulcers secondary to graft-versus-host disease. J Am Coll Clin Wound Spec. 2013;5(1):14-18. doi:10.1016/j.jccw.2014.04.001

151. Hurwitz RM, Haseman JH. The evolution of pyoderma gangrenosum. A clinicopathologic correlation. Am J Dermatopathol. 1993;15(1):28-33.

152. Fakhar F, Memon S, Deitz D, Abramowitz R, Alpert DR. Refractory postsurgical pyoderma gangrenosum in a patient with Beckwith Wiedemann syndrome: response to multimodal therapy. BMJ Case Rep. 2013;2013.

153. Tutrone WD, Green K, Weinberg JM, Caglar S, Clarke D. Pyoderma gangrenosum: dermatologic application of hyperbaric oxygen therapy. J Drugs Dermatol. 2007;6(12):1214-1219.

154. Niezgoda JA, Cabigas EB, Allen HK, Simanonok JP, Kindwall EP, Krumenauer J. Managing pyoderma gangrenosum: a synergistic approach combining surgical debridement, vacuum-assisted closure, and hyperbaric oxygen therapy. Plast Reconstr Surg. 2006;117(2):24e-28e. doi:10.1097/01.prs.0000200776.13868.02

155. Campton-Johnston S, Wilson J, Ramundo JM. Treatment of painful lower extremity ulcers in a patient with sickle cell disease. $J$ Wound Ostomy Continence Nurs. 1999;26(2):98-104.
156. Wethers DL, Ramirez GM, Koshy M, et al. Accelerated healing of chronic sickle-cell leg ulcers treated with RGD peptide matrix. RGD Study Group. Blood. 1994;84(6):1775-1779.

157. Laszlo J, Obenour W Jr., Saltzman HA. Effects of hyperbaric oxygenation on sickle syndromes. South Med J. 1969;62 (4):453-456.

158. Desforges JF, Wang MY. Sickle cell anemia. Med Clin North Am. 1966;50(6):1519-1532.

159. Rudge FW. Hyperbaric oxygen therapy in the treatment of sickle cell ulcers. J Hyperbaric Med. 1991;6(1):1-4.

160. Reynolds JD. Painful sickle cell crisis. Successful treatment with hyperbaric oxygen therapy. JAMA. 1971;216(12):1977-1978.

161. Stirnemann J, Letellier E, Aras N, Borne M, Brinquin L, Fain O. Hyperbaric oxygen therapy for vaso-occlusive crises in nine patients with sickle-cell disease. Diving Hyperb Med. 2012;42 (2):82-84.

162. Azik FM, Atay A, Kurekci AE, Ay H, Kibar Y, Ozcan O. Treatment of priapism with automated red cell exchange and hyperbaric oxygen in an 11-year-old patient with sickle cell disease. Turk J Haematol. 2012;29(3):270-273. doi:10.5505/ tjh.2012.78553

163. Canan H, Ulas B, Altan-Yaycioglu R. Hyperbaric oxygen therapy in combination with systemic treatment of sickle cell disease presenting as central retinal artery occlusion: a case report. $\mathrm{J} \mathrm{Med}$ Case Rep. 2014;8:370. doi:10.1186/1752-1947-8-370

164. Hammarlund C, Sundberg T. Hyperbaric oxygen reduced size of chronic leg ulcers: a randomized double-blind study. Plast Reconstr Surg. 1994;93(4):829-33; discussion 834.

165. Thistlethwaite KR, Finlayson KJ, Cooper PD, et al. The effectiveness of hyperbaric oxygen therapy for healing chronic venous leg ulcers: A randomized, double-blind, placebo-controlled trial. Wound Repair Regen. 2018;26(4):324-331. doi:10.1111/wrr.12657

166. Andrade SM, Santos IC. Hyperbaric oxygen therapy for wound care. Rev Gaucha Enferm. 2016;37(2):e59257.
Chronic Wound Care Management and Research

\section{Publish your work in this journal}

Chronic Wound Care Management and Research is an international, peer reviewed, open access, online journal publishing original research, reviews, editorials, and commentaries on the causes and management of chronic wounds and the major issues related to chronic wound management. Topics also include chronic wounds as comorbidities to other conditions, patient adherence to therapy, and the economic burden of chronic wounds. The manuscript management system is completely online and includes a very quick and fair peer review system, which is all easy to use. Visit http://www.dovepress.com/ testimonials.php to read real quotes from published authors. 